\title{
Interaction Between Acid-Labile Subunit and Insulin-like Growth Factor Binding Protein 3 Expressed in Xenopus Oocytes
}

\author{
Kyung-Yi Choi and Dong-Hee Lee* \\ Department of Life Science, The University of Seoul, Seoul 130-743, Korea
}

Received 9 August 2001, Accepted 2 November 2001

\begin{abstract}
The acid-labile subunit (ALS) associates with the insulinlike growth factor (IGF)-I or II, and the IGF binding protein-3 (IGFBP-3) in order to form a 150-kD complex in the circulation. This complex may regulate the serum IGFs by restricting them in the vascular system and promoting their endocrine actions. Little is known about how ALS binds to IGFBP3, which connects the IGFs to ALS. Xenopus oocyte was utilized to study the function of ALS in assembling IGFs into the ternary complexes. Xenopus oocyte was shown to correctly translate in vitro transcribed mRNAs of ALS and IGFBP3. IGFBP3 and ALS mRNAs were injected in a mixture, and their products were immunoprecipitated by antisera against ALS and IGFBP3. Contrary to traditional reports that ALS interacts only with IGF-bound IGFBP3, this study shows that ALS is capable of forming a binary complex with IGFBP3 in the absence of IGF. When cross-linked by disuccinimidyl suberate, the band that represents the ALSIGFBP3 complex was evident on the PAGE. IGFBP3 movement was monitored according to the distribution between the hemispheres. Following a localized translation in the vegetal hemisphere, IGFBP3 remained in the vegetal half in the presence of ALS. However, the mutant IGFBP3 freely diffused into the animal half, despite the presence of ALS, which is different from the wild type IGFBP3. This study, therefore, suggests that ALS may play an important role in sequestering IGFBP3 polypeptides via the intermolecular aggregation. Studies using this heterologous model will lead to a better understanding of the IGFBP3 and ALS that assemble into the ternary structure and circulate the IGF system.
\end{abstract}

Keywords: Acid-labile subunit (ALS), Insulin-like growth factor (IGF), IGF binding protein 3 (IGFBP3), Microinjection, Xenopus oocyte

*To whom correspondence should be addressed.

Tel: 82-2-2210-2170; Fax: 02-2210-2888

E-mail: leedh@uos.ac.kr

\section{Introduction}

The insulin-like growth factors (IGFs) and their binding proteins (IGFBPs) play an important role in cell proliferation, apoptosis, and differentiation. ALS is not a protein of the extra cellular matrix. IGFs and IGFBP3s circulate in ternary complexes with the acid-labile subunit (ALS), a glycosylated $85-\mathrm{kDa}$ member of the leucine-rich repeat (LRR) superfamily. ALS associates in the circulation with the insulin-like growth factor (IGF)-I or II, as well as with the IGF binding protein-3 (IGFBP-3), in order to form a 150-kilodalton complex. This complex may regulate the serum IGFs by restricting IGFs in the vascular system and promoting their endocrine actions (Firth et al., 1998).

The change in the molecular form of IGFBP3, which is caused by the incorporation into the ALS-IGFBP3 complex, allows IGFs to remain in the pool of growth factors for tissues without their potential hypoglycemic effects. Indeed, IGFs accumulate in postnatal plasma to levels reaching 1,000-fold that of insulin without nonspecific effects (Rechler and Clemmons, 1998). In order to form a complex with ALS to assemble into the $150-\mathrm{kDa}$ ternary structure, IGFBP3 have been known to require binding with IGFs. Recent reports, however, showed that IGF-free IGFBP-3/ALS complexes are plentiful in adult rat serum.

Ternary complexes are almost completely absent in the plasma of growth hormone (GH)-deficient animals. This is because plasma ALS and IGF-I originate mostly from the liver, where the transcription of both genes is GH-dependent. $\mathrm{GH}$, however, regulates directly or indirectly many other genes and processes, therefore, abnormalities of GH-deficient (Kho et al., 2000) animals cannot be attributed only to low levels of ALS, IGF-I, and ternary complexes (Ueki et al., 2000). Recent findings suggest that ALS may have roles other than the stabilization of plasma IGFs. Human synovial and ovarian fluids include significant levels of ALS transcripts. Fetal rats show considerable levels of the ALS gene expression, both in the cartilaginous and membranous bone, while in adult rats it appears in the kidney and wound filtrates. 
Little is known about the way ALS binds to IGFBP, which link IGFs to ALS. To study the role of ALS in assembling IGFs into the ternary complexes, we utilized Xenopus oocyte for a heterologous study. Xenopus oocytes have demonstrated efficiency and fidelity in the translation, processing, and functional expression of foreign proteins. Due to their large size and distinctive halves, Xenopus oocytes make it feasible to study the movement of protein by monitoring the migration between the two halves. This study investigates whether IGFBP3 plays an important role in the intermolecular aggregation. For this purpose, the diffusion of ALS and IGFBP3 were monitored according to the distribution of the two proteins between the hemispheres following a localized translation of the ALS and IGFBP3. This heterologous model will lead to a better understanding of the IGFBP3 and ALS association into the ternary structure and circulating IGF system.

\section{Materials and Methods}

Production of synthetic mRNAs The synthetic mRNAs of IGFBP3 and ALS were prepared from pSP6 that harbors respective cDNA according to Krieg and Melton (1984). The ALS cDNA was generated by a reverse transcriptase-polymerase chain reaction from pig liver total RNA. To prepare a mutant IGFBP3, the IGFBP3 cDNA was inserted into the EcoRI site of pAlter (Promega, USA) for mutagenesis, according to the manufacturer's protocol. A mutagenic DNA primer (Atg $\mathrm{GaC}$ gGG gAG gcG) was used to mutagenize IGFBP3 cDNA. This primer was used to mutagenize 228KGRKR into 228MDGEA. The altered sequences were sequenced for confirmation. The mutagenized cDNA was inserted into pSP6. Each construct was named pSPALS, pSPBP3, and pSPmBP3, respectively. To express a transmembrane control protein, synthetic mRNA was prepared from pSP6HAenv (Kim and Hanley, 2000). For transcription in vitro, CAP (m7GpppG) was supplemented in $10 \times$ molar excess of GTP to ensure the effective capping of the RNA transcript for the initial 45-min incubation, after which GTP was added to the concentration equivalent of CAP. The DNA templates were removed by incubating for $15 \mathrm{~min}$ at $37^{\circ} \mathrm{C}$ with RNase-free DNase I. The RNA transcript was purified by phenol extraction and ethanol precipitation.

Microinjection An ovary was manually excised from an adult Xenopus (Lee, 1998). The ovary was copiously washed in OR2 (82.5 mM NaCl, $2.5 \mathrm{mM} \mathrm{KCl}, 1.0 \mathrm{mM} \mathrm{CaCl}, 1.0 \mathrm{mM} \mathrm{MgCl}_{2}$, $3.8 \mathrm{mM} \mathrm{NaOH}, 1.0 \mathrm{mM} \mathrm{Na} \mathrm{HPO}_{4}, 5.0 \mathrm{mM}$ HEPES, pH 7.8) and incubated in fresh OR2 at $14^{\circ} \mathrm{C}$ until injection (Lee et al. 2001). Stage V-VI oocytes were manually defolliculated with a pair of fine forceps and injected with $50 \mathrm{nl}$ of an injection mixture that contained mRNA and labeling isotope, $\left[{ }^{35} \mathrm{~S}\right]$ methionine/cysteine by Eppendorf Micromanipulation System, and incubated in OR2 at $14^{\circ} \mathrm{C}$ before protein isolation. The mRNAs were injected normally at the vegetal pole.

$\left[{ }^{35}\right.$ S]Met/cys quenching and analysis of mRNA diffusion The rate of $\left[{ }^{35} \mathrm{~S}\right] \mathrm{met} / \mathrm{cys}$ quenching was analyzed according to the incorporation of $\left[{ }^{35} \mathrm{~S}\right] \mathrm{met} / \mathrm{cys}$ into IGFBP3 during the chase period.
Oocytes were injected with synthetic mRNA (25 ng) and $\left[{ }^{35} \mathrm{~S}\right] \mathrm{met} /$ cys $(0.5 \mu \mathrm{Ci} ; 1170 \mathrm{Ci} / \mathrm{mmol})$ in a $50 \mathrm{nl}$ injection mixture. The injected oocytes were pulse labeled by incubating in OR2. The incorporation rate was measured at 2, 3, 4, 6, and $15 \mathrm{~h}$ after injection. After $1 \mathrm{~h}$ of pulse labeling, a fraction of the oocytes were transferred to OR2 that contained $9.0 \mathrm{mM}$ cold met/cys. The incorporation rate was measured at 4,6 , and $15 \mathrm{~h}$ after injection. The incorporation was also measured for a narrow time range: 0.5 , $1,2,3 \mathrm{~h}$ of pulse labeling followed by $1 \mathrm{~h}$ of chase. The proteins were precipitated on $3 \mathrm{MM}$ paper in 10\% TCA and counted in a scintillation spectrometer. Following injection, the oocytes were incubated at $15^{\circ} \mathrm{C}$ in $\mathrm{OR} 2$, then cross-linked with disuccinimidyl suberate. The complexes were separated by reducing SDS/PAGE and visualized by autoradiography.

Diffusion of the injected mRNA was analyzed according to the time-dependent distribution of labeled IGFBP3 by hemisphere. After the mRNAs (50 ng per oocyte) were allowed to diffuse for 1, $2,3,4,5,6$, and $12 \mathrm{~h}$, the oocytes were injected with $\left[{ }^{35} \mathrm{~S}\right] \mathrm{met} / \mathrm{cys}$ $(0.5 \mu \mathrm{Ci}, 1170 \mathrm{Ci} / \mathrm{mmol})$ and incubated for $3 \mathrm{~h}$ in OR2. The oocytes were then frozen on dry ice and dissected along the equator.

Analysis of protein movement within oocytes The movement of the IGFBP3 and ALS was analyzed by a pulse-chase assay. The mRNA (25 ng) for ALS or IGFBP3 was injected with $\left[{ }^{35} \mathrm{~S}\right] \mathrm{met} / \mathrm{cys}$ $(0.5 \mu \mathrm{Ci})$ in a $50 \mathrm{nl}$ injection per oocyte into the vegetal hemisphere. Typically, 10 oocytes were injected in an experiment. As a control for the specific injection, the distribution of $\left[{ }^{35} \mathrm{~S}\right] \mathrm{met} /$ cys (and ALS mRNA) was determined immediately following injection as follows: five to eight oocytes were frozen by placing them on aluminum foil on a bed of dry ice and storing them at $-80^{\circ} \mathrm{C}$.

When the oocytes reached the consistency of butter during thawing, they were manually dissected along the equator by a chilled scalpel. The remaining oocytes were incubated in OR2 for 3 $\mathrm{h}$; then half of the oocytes were manually dissected and pooled by hemisphere. The residual half of the oocytes was chased in OR2 that contained 100 fold excess of cold met/cys for $12 \mathrm{~h}$. Each group was homogenized in a BIPIP buffer $(150 \mathrm{mM} \mathrm{NaCl}, 1 \mathrm{mM}$ PMSF, 1 mM EDTA, $1 \%$ Triton X-100, 0.5\% deoxycholate, $0.1 \%$ SDS, 10 $\mathrm{mM}$ Tris-HCl, $\mathrm{pH}$ 7.4). After a brief centrifugation, the supernatant was subjected to immunoprecipitation.

The movement of the HAenv, a transmembrane protein, was evaluated according to the time-dependent distribution between the two hemispheres. The oocytes were injected with in vitro transcribed HAenv mRNA (5 ng) and $\left.{ }^{35} \mathrm{~S}\right] \mathrm{met} / \mathrm{cys}(0.5 \mu \mathrm{Ci}, 1170$ $\mathrm{Ci} / \mathrm{mmole}$ ), then pulse labeled in OR2 for $3 \mathrm{~h}$. Half of the oocytes were removed and stored in $-80^{\circ} \mathrm{C}$ until the other half of oocytes were chased in OR2 that contained 100 fold excess cold met/cys for $12 \mathrm{~h}$. The oocytes were dissected into halves and grouped separately.

In the control experiments with ovalbumin, the oocytes were injected into the vegetal hemisphere with $10 \mathrm{ng}$ of ovalbumin mRNA and $0.5 \mu \mathrm{Ci}\left[{ }^{35} \mathrm{~S}\right] \mathrm{met} / \mathrm{cys}$, incubated in OR2 for $3 \mathrm{~h}$, and chased for $12 \mathrm{~h}$ in OR2 that contained 100 fold excess methionine. Those oocytes were dissected and pooled by hemisphere, as described in the HAenv experiment. Following homogenization in a BIPIP buffer, ovalbumin was immunoprecipitated in a way that was similar to the HAenv experiment, except for adding $10 \mu \mathrm{l}$ of 
affinity-purified polyclonal antibodies (Sigma, St. Louis, USA) against ovalbumin per $\mathrm{ml}$ of precipitation volume.

Fluorography After electrophoresis on a SDS gel that contained $7.5 \%$ polyacrylamide, the gel was fixed in $5.3 \%$ acetic acid for $1 \mathrm{~h}$ and subjected to fluorography. The gel was dehydrated by DMSO (dimethyl sulfoxide) during gentle shaking for $30 \mathrm{~min}$. After another treatment in fresh DMSO for $30 \mathrm{~min}$, the gel was impregnated with $20 \%$ (w/v) PPO (2,5 diphenyl oxazole) in DMSO with gentle shaking for $3 \mathrm{~h}$. The PPO and DMSO were removed by washing in double distilled water overnight. The washed gel was dried on $3 \mathrm{MM}$ paper and exposed to X-ray film at $-80^{\circ} \mathrm{C}$.

\section{Results}

The present study characterized whether the expressed ALS and IGFBP3 can interact in the absence of IGFs within Xenopus oocytes. This study also focused on the outcome of the potential intermolecular association between ALS and IGFBP3 in the oocytes. Following localized translation, the diffusion of the ALS or IGFBP3 was analyzed according to the time-dependent distribution of labeled proteins between the two hemispheres.

If the labeling $\left[{ }^{35} \mathrm{~S}\right] \mathrm{met} / \mathrm{cys}$ is not rapidly diluted in oocytes during the chase period, or if the injected mRNAs diffuse significantly across hemispheres during pulse labeling, then the distribution of radioactive proteins may not be a valid measurement of protein movement within the oocytes. Under these circumstances, the validity of the pulse-chase for monitoring IGFBP3 movement was tested by determining $\left.{ }^{35} \mathrm{~S}\right] \mathrm{met} / \mathrm{cys}$ quenching during the chase. The insignificance of mRNA diffusion was also validated during the labeling period within oocytes. The extent of $\left[{ }^{35} \mathrm{~S}\right] \mathrm{met} / \mathrm{cys}$ dilution was measured by a change in $\left[{ }^{35} \mathrm{~S}\right] \mathrm{met} / \mathrm{cys}$ incorporation into nascent polypeptides, including ALS, during the chase. Diffusion of mRNA was assayed according to the distribution of the labeled proteins between the oocyte hemispheres following injection of the ALS mRNAs.

Rapid dilution of the injected $\left[{ }^{35} \mathrm{~S}\right] \mathrm{met} / \mathrm{cys}$ during chase period A rapid dilution of the labeling $\left[{ }^{35} \mathrm{~S}\right] \mathrm{met} / \mathrm{cys}$ was verified by a comparison of $\left[{ }^{35} \mathrm{~S}\right] \mathrm{met} / \mathrm{cys}$ incorporation into IGFBP3 between the pulse and chase periods. Following coinjection of IGFBP3 mRNA and $\left[{ }^{35} \mathrm{~S}\right] \mathrm{met} / \mathrm{cys}$, the incorporation of $\left[{ }^{35} \mathrm{~S}\right] \mathrm{met} / \mathrm{cys}$ into IGFBP3 was measured up to $10 \mathrm{~h}$ after injection. Half of the incubated oocytes were transferred to OR2 that contained 100 fold excess of cold met/ cys. When incubated in a met/cys-free OR2, oocytes incorporate $\left[{ }^{35} \mathrm{~S}\right] \mathrm{met} / \mathrm{cys}$ into nascent polypeptides in a linear fashion (Fig. 1). In the presence of cold met/cys, however, the incorporation of $\left[{ }^{35} \mathrm{~S}\right] \mathrm{met} / \mathrm{cys}$ was significantly reduced within $1 / 2 \mathrm{~h}$ of the chase, and virtually eliminated within $1 \mathrm{~h}$ of the chase. This clearly indicates that oocytes readily take up the cold met/cys and the internal pool of $\left[{ }^{35} \mathrm{~S}\right] \mathrm{met} / \mathrm{cys}$ become rapidly quenched.
The rate of $\left[{ }^{35} \mathrm{~S}\right] \mathrm{met} / \mathrm{cys}$ incorporation into IGFBP3 was minimized within $1 / 2$ to $2 \mathrm{~h}$ after the oocytes were placed in an OR2 medium that contained 100 fold excess of unlabeled $\left[{ }^{35} \mathrm{~S}\right] \mathrm{met} / \mathrm{cys}$. These parallel experiments indicate that the labeled $\left[{ }^{35} \mathrm{~S}\right] \mathrm{met} / \mathrm{cys}$ pool can be diluted in the oocytes within $2 \mathrm{~h}$ during the chase period. Also, nascent polypeptides, including IGFBP3, are no longer significantly labeled after 2 $\mathrm{h}$ into the chase period.

Insignificant IGFBP3 mRNA diffusion during labeling period Since diffusion of the mRNA may lessen the validity for the localized expression of IGFBP3, the diffusion of injected mRNA was evaluated by the distribution of labeled IGFBP3 between hemispheres. The oocytes were injected with $50 \mathrm{ng}$ of IGFBP3 and incubated in an OR2 medium in order to allow the IGFBP3 mRNA to diffuse up to $12 \mathrm{~h}$. After these time periods, the oocytes were injected with $0.5 \mu \mathrm{Ci}$ of $\left[{ }^{35} \mathrm{~S}\right] \mathrm{met} / \mathrm{cys}$ at the equator and incubated for $3 \mathrm{~h}$ in OR2. After the 3-h labeling, the oocytes were cleaved into halves and pooled separately by half. Proteins were extracted in a BIPIP buffer and counted in a scintillation spectrometer after precipitation on $3 \mathrm{MM}$ paper by $10 \% \mathrm{TCA}$.

Fig. 2 shows the distribution of the radioactive IGFBP3 after allowing IGFBP3 mRNA to diffuse for the indicated periods. Based upon the distribution of the labeled IGFBP3, IGFBP3 mRNAs do not significantly diffuse up to $7 \mathrm{~h}$ following injection. Most radioactive IGFBP3 (93\%) are still localized in the vegetal half at least $7 \mathrm{~h}$ following injection (i.e. $4 \mathrm{~h}$ of diffusion and $3 \mathrm{~h}$ of labeling). These results

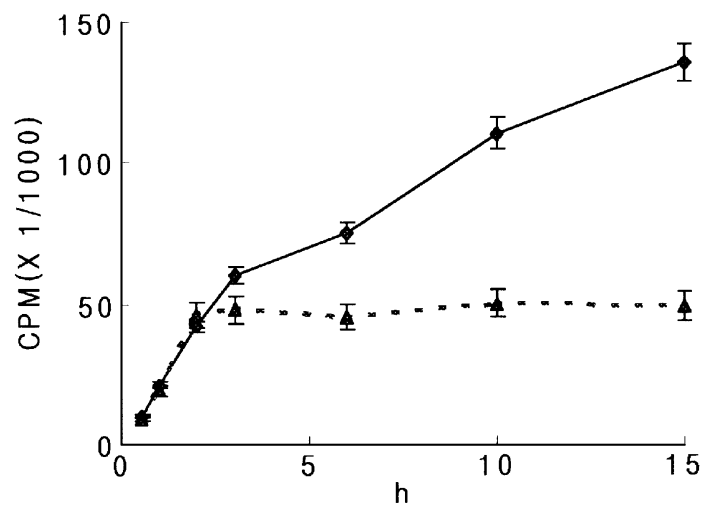

Fig. 1. Rapid quenching of $\left[{ }^{35} \mathrm{~S}\right] \mathrm{met} / \mathrm{cys}$ during chase. Oocytes were co-injected with $\left[{ }^{35} \mathrm{~S}\right] \mathrm{met} / \mathrm{cys}$ and IGFBP3 mRNAs. Incorporation of $\left.{ }^{[35} \mathrm{S}\right] \mathrm{met} / \mathrm{cys}$ into proteins was measured following incubations in OR2 in the presence (broken) or absence (straight) of $100 \times$ molar excess of cold met/cys. The arrow indicates the initiation of the chase. The proteins were extracted in a BIPIP buffer and precipitated on $3 \mathrm{MM}$ paper in $10 \%$ TCA. The time refers to the periods elapsed since the injection of mRNA and $\left[{ }^{35} \mathrm{~S}\right] \mathrm{met} / \mathrm{cys}$. The incorporation kinetics were $0.5,1,2,3$, and $4 \mathrm{~h}$ to analyze the kinetics after injecting the identical amounts of mRNA and $\left[{ }^{35}\right.$ S]met/cys. The $\mathrm{X}$ and $\mathrm{Y}$ plots represent the chase periods after $1 \mathrm{~h}$ labeling and the radioactivity of labeled IGFBP3, respectively. 


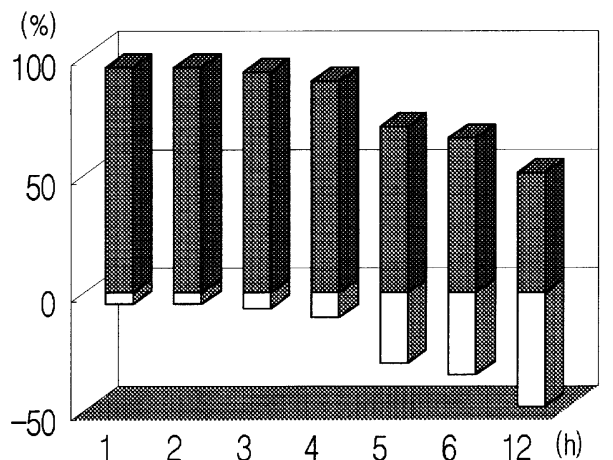

Fig. 2. Analysis of IGFBP3 mRNA diffusion. IGFBP3 mRNA diffusion was analyzed according to the time-dependent distribution of the pulse labeled IGFBP3. IGFBP3 mRNA (50 ng per oocyte) was injected into the vegetal pole and allowed to diffuse during incubation in OR2 for $1,2,3,4,5,6$, and $12 \mathrm{~h}$. After each incubation, the oocytes were injected at the equator with $0.5 \mu \mathrm{Ci}$ of $\left[{ }^{35} \mathrm{~S}\right] \mathrm{met} / \mathrm{cys}$ and placed in OR2 for $3 \mathrm{~h}$. The oocytes were dissected into hemispheres. IGFBP3 was immunoprecipitated by antisera against IGFBP3 in a BIPIP buffer. IGFBP3 was further precipitated in 10\% (Fig. 1). Dark bars refer to the portion expressed in the vegetal half, while light ones refer to the animal half. The $\mathrm{X}$ and $\mathrm{Y}$ plots refer to the chase time after $3 \mathrm{~h}$ pulse labeling and the percentage of radiolabeled IGFBP3 in each hemisphere, respectively.

strongly indicate that IGFBP3 mRNA diffusion is insignificant during the pulse period in this study. Thus, the rate of mRNA diffusion does not jeopardize the interpretation of the IGFBP3 movement within the lumen of ER in this study. Combining the rapid dilution of the $\left[{ }^{35} \mathrm{~S}\right] \mathrm{met} / \mathrm{cys}$ during the chase and the insignificant diffusion of IGFBP3 mRNA for $7 \mathrm{~h}$ after injection, a time-dependent distribution between hemispheres practically represents the movement of IGFBP3 within the oocytes.

Free movement of IGFBP3 in the oocytes The movement of the IGFBP3s was investigated by a pulse-chase assay according to Ceriotti and Colman (1988). IGFBP3 mRNA (25 ng) was co-injected with $\left[{ }^{35} \mathrm{~S}\right] \mathrm{met} / \mathrm{cys}(0.5 \mu \mathrm{Ci})$ in a $50 \mathrm{nl}$ injection volume either into the vegetal or animal hemisphere. There was no apparent difference in the protein expression, whether or not the mRNA was initially injected in the vegetal or animal hemisphere (Fig. 3). Despite different environments, ALS and IGFBP3 were expressed with each specific molecular weight and formed a binary complex.

In order to analyze the movement of nascent polypeptides in oocytes, the time-dependent distribution of labeled polypeptide between the vegetal and animal half was examined. Following a vegetal injection of each mRNA (ALS, IGFBP3, mutant IGFBP3) and labeling, the oocytes were chased $3 \mathrm{~h}$ in OR2 that contained 100 fold excess of nonradioactive met/cys. The remaining half of the oocytes was chased in OR2 for $6 \mathrm{~h}$. When the proteins were immunoprecipitated using each specific antibody and

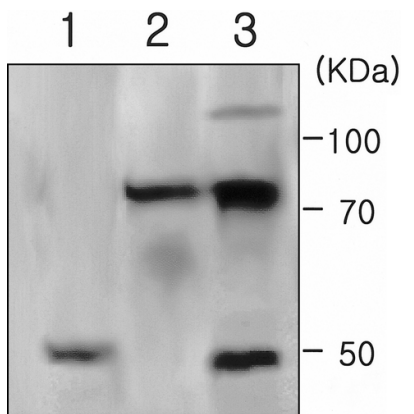

Fig. 3. ALS and IGFBP3 expressed in oocytes. The mRNAs of IGFBP3 and ALS were injected singularly or in mixture into the oocyte. Lanes 1, 2, and 3 denote proteins that were translated from mRNAs of IGFBP3, ALS, and co-injected mRNAs of ALS with IGFBP3. In lane 3, the oocytes were treated with crosslinking agents following co-injection. Anti-ALS and anti-IGFBP3 antibodies precipitated the cross-linked complex. Three classes of bands were evident. The top band represents the ALS-IGFBP3 binary complex. The two lower bands denote ALS and IGFBP3, which do not participate in the ALS-IGFBP3 complex.

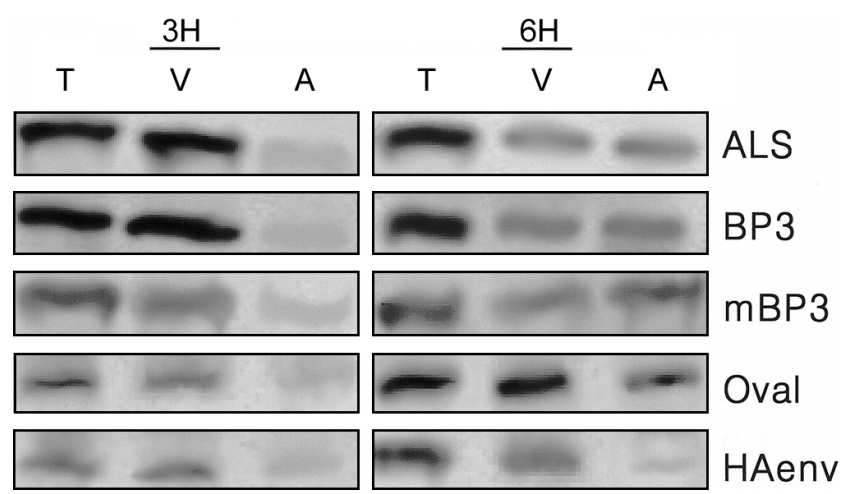

Fig. 4. Free movement of ALS, BP3, and $\mathrm{mBP} 3$ in the oocytes. ALS, IGFBP3, and mutant IGFBP3 mRNAs were injected singularly with $\left[{ }^{35} \mathrm{~S}\right] \mathrm{met} / \mathrm{cys}$ into the vegetal half. The injected oocytes were incubated in OR2 media for one hour and chased for 3 and $6 \mathrm{~h}(3 \mathrm{H}$ and $6 \mathrm{H})$. The oocytes were dissected into vegetal (V) and animal (A) halves, which were pooled separately. Proteins from the dissected halves or total (T) oocytes were immunoprecipitated and electrophoresed on a $7.5 \%$ gel. ALS, BP3, and mBP3 appear to freely move across the equator and reach equilibrium within $12 \mathrm{~h}$ of chase. (HAenv is the transmembrane control; Ovalbumin is the control for the secretory protein.)

subjected to fluorography, the fluorograph from the experiment showed the distribution of each protein at the 3 and $6 \mathrm{~h}$ chase (Fig. 4). At the $3 \mathrm{~h}$ chase time point, the proteins were mainly localized in the vegetal half. The chase, however, was extended to $6 \mathrm{~h}$ and the protein distribution appeared to reach an equilibrium between the two halves.

In the control experiments in order to monitor a secretory protein's movement within the oocytes, the oocytes were injected into the vegetal pole with ovalbumin (oval) mRNA and 

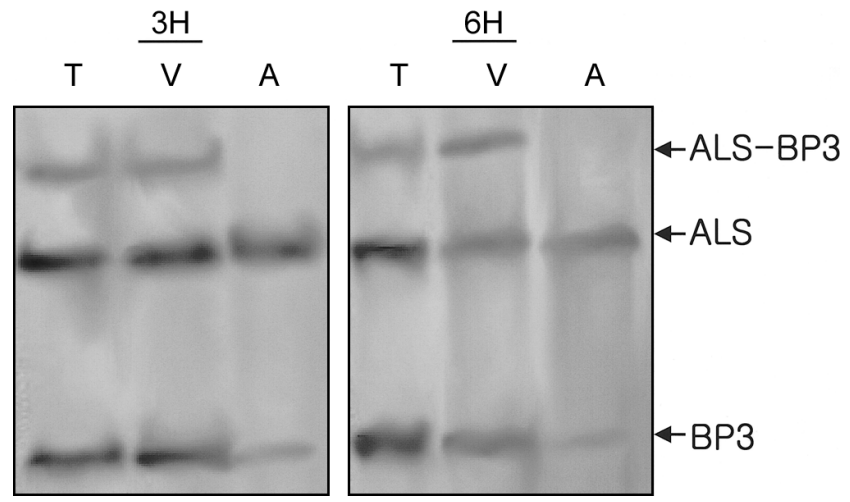

Fig. 5. Localization of IGFBP3 in the presence of ALS. The ALS mRNA was injected into the vegetal half of 10 oocytes and incubated in an OR2 medium for $3 \mathrm{~h}$. Later, the oocytes were injected with IGFBP3 mRNA and labeled for $1 \mathrm{~h}$. The oocytes were chased for 3 or $6 \mathrm{~h}$. The movement of IGFBP3 in the presence of ALS was analyzed according to the distribution of IGFBP3 between the halves. The majority of IGFBP3 appeared to remain in the vegetal half, which is different than Fig. 4, even though the chase was performed for up to $6 \mathrm{~h}$.

$\left[{ }^{35} \mathrm{~S}\right] \mathrm{met} / \mathrm{cys}$, then incubated in OR2 for $3 \mathrm{~h}$. Half of the incubated oocytes were removed. The remaining halves were chased in OR2. The oocytes were cleaved at the equator, pooled by hemisphere, and homogenized in a BIPIP buffer. When immunoprecipitated by an anti-oval antibody, the ovalbumin was detected mostly in the vegetal half during the 3-h chase; however, it moved readily in the oocytes during the 6-h chase. In the control experiments with HAenv, the oocytes were injected into the vegetal pole with HAenv mRNA and $\left[{ }^{35} \mathrm{~S}\right] \mathrm{met} /$ cys. Immunoprecipitation and fluorography determined the movement of HAenv. The HAenv, the ER transmembrane control, showed no change in terms of its distribution pattern between the hemispheres, even after the 6-h chase period. The labeled HAenv appears to remain in the vegetal half, where its mRNA and labeling isotope were injected throughout the labeling and chasing periods.

\section{Retardation of IGFBP3 movement in the presence of wild} type ALS The oocytes were injected into the vegetal pole with the ALS mRNA. Three hours later, the oocytes were injected with IGFBP3 mRNA and $\left[{ }^{35} \mathrm{~S}\right] \mathrm{met} / \mathrm{cys}$. The movement of the IGFBP3 was analyzed according to a identical procedure that was used for monitoring the proteins in Fig. 4. The ALS was primarily located in the vegetal half after the 3-h chase. During the 6-h chase, the ALS diffused to an equilibrium between the two hemispheres. The timedependent distribution of the ALS indicates that the protein can move freely in the oocytes.

When IGFBP3 was expressed in the oocytes, and its distribution was analyzed by the oocyte half, its movement appeared to be greatly affected, depending on the presence of ALS in the oocytes. Fig. 5 shows the distribution of ALS and

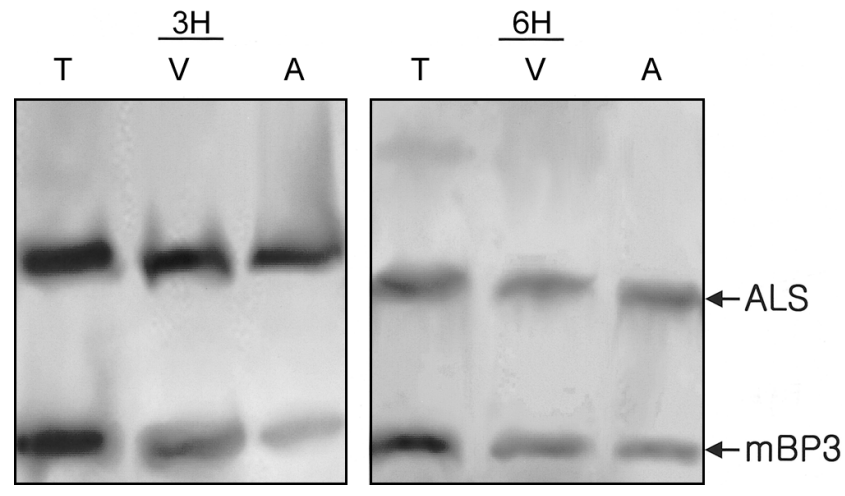

Fig. 6. Free movement of mutant IGFBP3 despite ALS. Following injection of ALS mRNA, 10 oocytes were incubated for $3 \mathrm{~h}$. They were then injected again with mutant IGFBP3 mRNAs and $\left[{ }^{35} \mathrm{~S}\right] \mathrm{met} / \mathrm{cys}$ (described in Fig. 5). Following chase for 3 and $6 \mathrm{~h}$, the oocytes were cleaved by half and pooled separately. The halves were homogenized in a BIPIP buffer and subjected to immunoprecipitation using antisera against the two proteins. The movement of IGFBP3 appeared to freely diffuse across the equator and reach equilibrium within $6 \mathrm{~h}$ of incubation.

IGFBP3 after the 1-h labeling that was followed by a 3-h chase. At that time, the majority of IGFBP3 and ALSIGFBP3 complex are restricted to the vegetal half, where mRNAs and the labeling isotope were injected. Despite the 6$h$ chase, the distribution of IGFBP3 and ALS-IGFBP3 complex were restricted in the vegetal half. It showed a lack of movement in the oocytes, which is different than the IGFBP3 that are singularly expressed in the oocytes. This may be an indication that IGFBP3 was restricted in the vegetal half, most likely as a component of the ALS-IGFBP3 complex.

Free movement of mutant IGFBP3 irrespective of ALS Following the initial ALS mRNA injection, the oocytes were incubated for $3 \mathrm{~h}$. The oocytes were injected again with mutant IGFBP3 mRNAs and $\left[{ }^{35}\right.$ S $]$ met/cys. Following the chase ( 3 or $6 \mathrm{~h}$ ), the oocytes were divided by half and pooled separately. The halves were homogenized in a BIPIP buffer and subjected to immunoprecipitation using antisera against the two proteins. Fig. 6 shows that the movement of the mutant IGFBP3 appeared to diffuse freely across the equator and reach equilibrium within $6 \mathrm{~h}$ of incubation. This is very different from the wild type IGFBP3. Along with the results for the wild type IGFBP3, the free movement of the mutant IGFBP3 strongly suggests that ALS is capable of binding to IGFBP3 in the absence of IGF, and it can retard the free movement of IGFBP3 in the oocytes.

\section{Discussion}

This study demonstrates that the messages of ALS and IGFBP3 are translated, and their products interact to form a complex in the oocytes, despite the different physiological 
environments. Following the translation, ALS and IGFBP3 were shown to diffuse to equilibrium between the two hemispheres. Due to the insignificance in the mRNA diffusion during pulse labeling and lack of $\left[{ }^{35} \mathrm{~S}\right] \mathrm{met} / \mathrm{cys}$ incorporation during chase, the observed equilibrium practically represents the time-dependent movement of the ALS and IGFBP3 that is expressed in the oocytes. In the presence of ALS, however, the IGFBP3 diffusion was significantly affected. On the other hand, the mutant IGFBP3 appeared the least affected in diffusing to the other half in the presence of ALS. This study shows that ALS may inhibit the IGFBP3 diffusion, most likely by forming a less mobile ALS-IGFBP3 complex within the oocytes.

The postulated retarded movement of IGFBP3 in the presence of ALS, however, may indicate a potential interaction between ALS and IGFBP3 in vivo. The retarded movement may be indicative of the spontaneous assembly of the two polypeptides. According to the retarded movements of the ALS-IGFBP3 complex, therefore, it is tempting to suggest that the interactions between ALS and IGFBP3 lead to insolubility and exclusion in oocytes. IGFBP3 appears to form a less mobile aggregate in the oocytes upon encountering ALS. When IGFBP3 accompanies ALS, IGFBP3s might significantly lose its mobility in the oocytes.

ALS may serve as a driving force in the ALS-IGFBP3 assembly, such as a nucleating factor for ALS-IGFBP3 aggregates-in this case, within the rough endoplasmic reticulum. The retarded movements of IGFBP3 in the presence of ALS suggest that the interactions between ALS and IGFBP3 lead to insolubility and exclusion in the ER. ALS may play a significant role in assembling the ALS-IGFBP3 complex, even though IGFBP3 interactions are likely the driving force in assembling into the ternary complex that consists of IGFs. A high concentration of IGFBP3 in ER may serve as a driving force for IGFBP3s' precipitation into an aggregate, finalizing the IGFBP3-ALS complex. The intermolecular interaction between ALS and IGFBP3s will increase as the concentration of IGFBP3s rises in the oocytes.

Each of the oocytes was injected into the vegetal pole with $25 \mathrm{ng}$ (the amount injected in this study). This may be sufficient for the mRNAs of ALS and IGFBP3 to saturate the entire ER membranes in the oocytes. On the basis of the $\left[{ }^{35} \mathrm{~S}\right] \mathrm{met} / \mathrm{cys}$ incorporation kinetics (Fig. 1), and no apparent competition between the two mRNAs for the translation machinery, the ALS and IGFBP3 would accumulate at approximately $2.4 \mathrm{ng}\left(0.1 \mathrm{pmol}\right.$ or $5 \times 10^{10}$ molecules $)$ each per hour in this study from the internal met/cys pool of 320 pmoles (Gourdon and Lane, 1971). The ER lumen occupies less than $15 \%$ (or $100 \mathrm{nl}$ ) of the oocyte in volume, and would contain ALS-IGFBP3s approximately at $1.6 \times 10^{-3} \mathrm{M}$ at the end of the 6-h incubation (Shih et al., 1979). The ER lumen likely maintains a sufficient concentration for intermolecular interaction between ALS and IGFBP3.

ALS and IGFBP3 may aggregate significantly due to their ample presence in the ER lumen. The intermolecular ALS-
IGFBP3 aggregation may explain the retarded movement of IGFBP3 in the oocytes. Oocyte ER lumen is instantly loaded with ALS and IGFBP3 in order for high-molecular-weight oligomers to form. The retarded movement of IGFBP3 in the presence of ALS is surprising since the majority of ALS and IGFBP3 reside in the ER, where all of the nascent polypeptides have a strong tendency for free movement.

The observed lack of wild type IGFBP3 diffusion under the presence of ALS strongly suggests that ALS readily interacts with IGFBP3. The resulting binary complexes are less mobile than their monomeric components. Considering that the molecules of IGFBP3 diffuse to the animal half, the extent of the ALS-IGFBP3 interaction is very strong. Also, the amount of pre-existing ALS in oocytes might be sufficient to interact with the majority of nascent IGFBP3 polypeptides.

The mutant IGFBP3's free movement also supports the previous claim. The free movement of the mutant IGFBP3 under the presence of ALS strongly supports the importance of ALS in forming the insoluble ALS-IGFBP3 complex by direct binding. The mutant IGFBP3 was not expected to interact with ALS, since a significant charge reversal was introduced, and its binding site to ALS has been disrupted (Firth et al. 1998). The mutant IGFBP3 was shown to diffuse freely to the other half, which is different than the wild type counterpart. The free movement of mutant IGFBP3, together with the retarded movement of IGFBP3 under the wild type ALS, suggests that ALS interacts with IGFBP3 in the absence of IGFs. Also, ALS is capable of delaying the IGFBP3 diffusion, most likely by incorporating IGFBP3 into a less mobile complex in the ER lumen. A future study may be necessary to determine the rate of interaction between IGFBP3 and ALS in the presence of IGFs. Kinetics of association and dissociation of the ALS-IGFBP3 against decrements of ALS concentration may provide a meaningful lead in determining the postulated role as a perennial binding factor in vivo to IGFBP3 in the absence of IGFs.

\section{References}

Adashi, E. Y., Resnick, C. E., Hurwitz, A., Ricciarelli, E., Hernandez, E. R., Roberts, C. T. and Leroith, D. (1993) The role of insulin-like growth factors and epidermal growth factorrelated peptides in intraovarian in the pig ovary. J. Reprod. Fertil. Suppl. 48, 117-125.

Baxter, R. C. and Dai, J. (1994) Purification and characterization of the acid-labile subunit of rat serum insulin-like growth factor binding protein complex. Endocrinology 134, 848- 852.

Baxter, R. C., Martin, J. L. and Benian, V. A. (1989) High molecular insulin-like growth factor binding protein complex. $J$. Biol. Chem. 264, 11843-11848.

Blair, H. T., McCutcheon, S. N., Mackenzie, D. D., Gluckman, P. D., Ormsby, J. E. and Brier, B. H. (1989) Response to divergent selection for plasma concentrations of insulin-like growth factor-1 mice. Genet. Res. 53, 187-191.

Boisclair, Y. R., Seto, D., Hsieh, S., Hurst, K. R. and Ooi, G. T. (1996) Organization and chromosomal localization of the gene 
encoding the mouse acid labile subunit of the insulin-like growth factor binding complex. Proc. Natl. Acad. Sci. USA 93, 10028-10033.

Boisclair, Y. R., Tremblay, M. L. and Ooi, G. T. (1997) Targeted inactivation of the acid-labile subunit gene of the $150 \mathrm{kDa}$ IGF-binding protein complex. Proceedings of the 79th Annual Meeting of the Endocrine Society, Minneapolis, p 345 (Abstr.).

Ceriotti, A. and Colman, A. (1988) Binding to membrane proteins within the endoplasmic reticulum cannot explain the retention of the glucose-regulated protein GRP78 in Xenopus oocytes. EMBO J. 7, 633-638.

Ceriotti, A., Fabbrini, M. S., Zoppe, M., Bollini, R. and Vitale, A. (1991) Expression of the wild-type and mutated vacuolar storage protein phaseolin in Xenopus oocytes reveals relationships between assembly and intracellular transport. Eur. J. Biochem. 202, 959-968.

Cohick, W. S. (1998) Role of the insulin-like growth factors and their binding proteins in lactation. J. Dairy Sci. 81, 1769-1777.

Colman, A. (1984) Translation of eukaryotic messenger RNA in Xenopus oocytes; in Transcription and Translation, Hames, B. D. and Higgins, S. J. (eds.), pp. 271-302, IRL Press, Washington, DC.

Cox, N. M. (1997) Control of follicular development and ovulation rate in pigs. J. Reprod. Fert. Suppl. 52, 31-46.

Delhanty, P. and Baxter, R. C. (1996) The cloning and expression of the baboon acid-labile subunit of the insulin-like growth factor binding protein complex. Biochem. Biophys. Res. Commun. 227, 897-902.

Eisenmann, J. E., Patterson, D. F. and Froesch, E. R. (1984) Body size parallels insulin-like growth factor I levels but not growth hormone secretory capacity. Acta Endocrinol. 106, 448-453.

Etherton, T. D. and Kensinger, R. S. (1984) Endocrine regulation of fetal and postnatal meat animal growth. J. Animal Sci. 59, 511-528.

Gluckman, P. D., Douglas, R. G., Ambler, G. R., Breier, B. H., Hodgkinson, S. C., Koea, J. B. and Shaw, J. H. F. (1991) The endocrine control of insulin-like growth factor I. Acta Padiatr. Scand. Suppl. 372, 97-105.

Gourdon, J. B., Lane, C. D. and Woodland, H. R. (1971) Use of frog egg and oocytes for the study of messenger RNA and its translation in living cells. Nature 233, 177-182.

Hurtley, S. M. and Helenius, A. (1989) Protein oligomerization in the endoplasmic reticulum. Annu. Rev. Cell Biol. 5, 277-307.

Jones, J. I. and Clemmons, D. R. (1995) Insulin-like growth factors and their binding proteins: biological actions. Endocrine Rev. 16, 3-34.

Kaelin, W. G., Pallas, D. C., Decaprio, J. A., Kaye, F. J. and Livingston, D. M. (1991) Identification of cellular proteins that can interact specifically with $\mathrm{T} / \mathrm{E} 1 \mathrm{~A}-$ binding region of the retinoblastoma gene product. Cell 64, 521-532.

Kawata, E. E., Galili, G., Smith, L. D. and Larkins, B. A. (1988) Translation in Xenopus oocytes of mRNA transcribed in vitro; in Plant Molecular Biology Manual, Gelvin, S. B. and Schilperoort, R. A. (eds.), pp. 1-22, Kluwer Academic Publishers, Dordrecht, Belgium.

Kim, H. Y. and Hanley, M. R. (2000) Comparison of membrane currents in Xenopus oocytes in response to injection of calcium influx factors (CIF) and depletion of intracellular calcium stress. J. Biochem. Mol. Biol. 33, 202-207.

Klindt, J., Buonomo, F. C. and Yen, J. T. (1992) Administration of porcine somatotropin by sustained-release implant: growth and endocrine responses in genetically lean and obese barrows and gilts. J. Animal Sci. 70, 3721-3733.

Koh, H. J., Park, H. H. and Lee, C. E. (2000) Regulation of IgE and Type 2 IgE recepter expression by Insulin-like growth factor-1: Role of STAT6 and NF-кB. J. Biochem. Mol. Biol. 33, 454-462.

Krieg, P. A. and Melton, D. A. (1984) Functional messenger RNAs are produced by SP6 in vitro transcription of cloned cDNAs. Nucleic Acids Res. 12, 7057-7070.

Kroonsberg, C., McCutcheon, S. N., Siddiqui, R. A., Mackenzie, D. D., Blair, H. T., Ormsby, J. E., Breier, B. H. and Gluckman, P. D. (1989) Reproductive performance and fetal growth in female mice from lines divergently selected on the basis of plasma IGF-I concentrations. J. Reprod. Fert. 87, 349-353.

Lamberson, W. R., Safranski, T. J., Bates, R. O., Keisler, D. H. and Matteri, R. L. (1995) Relationships of serum insulin-like growth factor I concentrations to growth, composition, and reproductive traits of swine. J. Animal Sci. 73, 3241-3245.

Lamberson, W. R., Sterle, J. A. and Matteri, R. L. (1996) Relationships of serum insulin-like growth factor II concentrations to growth, compositional, and reproductive traits of swine. J. Animal Sci. 74, 1753-1756.

Lee, C. Y. and Rechler, M. M. (1995a) A major portion of the 150-kilodalton insulin-like growth factor binding protein (IGFBP) complex in adult rat serum contains unoccupied proteolytically nicked IGFBP-3 that binds IGF-II preferentially. Endocrinology 136, 668-678.

Lee, C. Y. and Rechler, M. M. (1995b) Purified rat acid-labile subunit and recombinant human insulin-like growth factor (IGF)-binding protein-3 can form a 150-kilodalton binary complex in vitro in the absence of IGFs. Endocrinology 136, 4982-4989.

Lee, C. Y. and Rechler, M. M. (1996) Proteolysis of insulin-like growth factor (IGF) binding protein-3 (IGFBP-3) in 150kilodalton IGFBP complexes by a cation-dependent protease activity in adult rat serum promotes the release of bound IGF-I. Endocrinology 137, 2051-2058.

Lee, D.-H. (1998) Characterization of $27 \mathrm{~K}$ zein as a transmembrane protein. J. Biochem. Mol. Biol. 31, 196-200.

Kang, S.-H. and Choi, Y.-J. (2001) Characterization of Protein disulfide isomerase during lactoferin polypeptide structural maturation in the endoplasmic reticulum. J. Biochem. Mol. Biol. 34, 102-108.

Leong, S. R., Baxter, R. C., Camerato, T., Dai, J. and Wood, W. I. (1992) Structure and functional expression of the acid-labile subunit of the insulin-like growth factor-binding protein complex. Mol. Endocrinol. 6, 870-876.

Liu, J. P., Baker, J., Perkins, A. S., Robertson, E. J. and Efstratiadis, A. (1993) Mice carrying null mutations of the genes encoding insulin-like growth factor I (Igf-1) and type 1 IGF receptor (IGFr). Cell 75, 59-72.

Melton, D. A., Krieg, P. A., Rebaglianti, M. R., Maniatis, T., Zinn, K. and Green, M. R. (1984) Efficient in vitro synthesis of biologically active RNA and RNA hybridization probes from plasmids containing a bacteriophage SP6 promoter. Nucleic Acids Res. 12, 7035-7056.

Owens, P. C., Moyse, K. J., Walton, P. E., Priebe, I., Harrison, D. T., Luxford, B. G. and Campbell, R. G. (1993) Genetic differences in insulin-like growth factors and binding proteins: 
relationship to growth rate. Proceedings of the 75th Annual Meeting of the Endocrine Society, Las Vegas, p 266 (Abstr.).

Rechler, M. M. and Clemmons, D. R. (1998) Regulatory actions of insulin-like growth factor-binding proteins. Trends Endocrinol. Metab. 9, 176-183.

Richter, J. D. and Smith, L. D. (1981) Differential capacity for translation and lack of competition between mRNAs that segregate to free and membrane-bound polysomes. Cell 27, 183-191.

Rosenfeld, R. (1991) Insulin-like growth factors: the ovarian connection. Human Reprod. 6, 1213-1219.

Shih, R. J., O'Connor, C. M., Kristen, K. and Smith, L. D. (1979) Kinetic Analysis of amino acid pools and protein analysis in amphibian oocytes and embryos Dev. Biol. 66, 172-182.

Smith, D. G. and Johnson, K. S. (1988) Single-step purification of polypeptides expressed in Escherichia coil as fusion with glutathione S-transferase. Gene 67, 31-40.
Ueki I., Ooi, G. T., Tremblay, M. L., Hurst, K. R. and Boisclair, Y. R. (2000) Inactivation of the acid labile subunit gene in mice results in mild retardation of postnatal growth despite profound disruptions in the circulating insulin-like growth factor system. Proc. Nat. Acad. Sci. USA 97, 6868-6873.

Wallace, J. C., Galili, G., Kawata, G. G., Lending, C. R., Kriz, A. L., Bracker, C. E. and Larkins, B. A. (1988) Location and interaction of the different types of zeins in protein bodies. Biochem. Physiol. Pflanzen. 183, 107-114.

Winder, S. J., Tuvey, A. and Forsyth, I. A. (1989) Stimulation of DNA synthesis in cultures of ovine mammary epithelial cells by insulin and insulin-like growth factors. J. Endocrinol. 123, 319-326.

Zapf, J., Born, W., Chang, J. Y., James, P., Froesch, E. R. and Fisher, J. A. (1988) Isolation and NH2-terminal amino sequences of rat serum carrier proteins for insulin-like growth factor. Biochem. Biophys. Res. Commun. 156, 1187-1194. 